\title{
ВОССТАНОВЛЕНИЕ
}

СТАЛИНГРАДА И ОБЛАСТИ

DOI: https://doi.org/10.15688/jvolsu4.2018.1.9

UDC 94(47).084.8:314.045

Submitted: 23.07.2017

BBC 63.3(2)621:60.72.3

Accepted: 21.11.2017

\section{DEMOGRAPHIC CONSEQUENCES OF THE STALINGRAD BATTLE ${ }^{1}$}

\author{
Evgeniy F. Krinko \\ Southern Scientific Center of RAS, Rostov-on-Don, Russian Federation \\ Maksim V. Medvedev \\ Southern Scientific Center of RAS, Rostov-on-Don, Russian Federation
}

\begin{abstract}
The first information about the losses of the Red Army and the Wehrmacht in the Battle of Stalingrad, the deaths of the civilian population of the Stalingrad region during the Nazi occupation were published back in the years of the Great Patriotic War. Later many authors investigated these questions. In the early 1990s, Soviet losses were calculated by a group of specialists of the General Staff under the leadership of Colonel General G. F. Krivosheev. However, there are alternative points of view on this issue. In general, the demographic consequences of the Battle of Stalingrad as a complex scientific problem have not been sufficiently studied.

The authors of the article consider different types of losses, mention major military associations and units that took part in the fights for Stalingrad, as well as the number of soldiers in military units. The special attention is paid to the losses of civilian population. According to the most conservative estimates, the military losses of both parties in the Stalingrad battle amounted to at least 2-2.5 million people. The population of the Stalingrad region declined as a result of evacuation, hostilities and occupation by more than 0.5 million people, or nearly by a quarter. Mass losses led to significant deformations in the demographic structure of the population of the Stalingrad and neighboring regions. The number of working age men suffere the especially sharp decline. These deformations had determined the unfavorable trends in the demographic development of the region for many decades.

In the introductory part of the paper E.F. Krinko describes the main types of losses and correlation of military forces by the beginning of the Stalingrad Battle. The conclusions made by the author summarize the overall research results.

M. V. Medvedev reveals specific types of military and civilian losses suffered as a result of the Stalingrad Battle.

Key words: Great Patriotic War, Battle of Stalingrad, Stalingrad region, Red Army, Wehrmacht, demographic processes.

Citation. Krinko E.F., Medvedev M.V. Demographic Consequences of the Stalingrad Battle. Vestnik Volgogradskogo gosudarstvennogo universiteta. Seriya 4, Istoriya. Regionovedenie. Mezhdunarodnye otnosheniya [Science Journal of Volgograd State University. History. Area Studies. International Relations], 2018, vol. 23, no. 1, pp. 91-104. (in Russian). DOI: https://doi.org/10.15688/jvolsu4.2018.1.9

УДК 94(47).084.8:314.045

ББК 63.3(2)621:60.72.3

Дата поступления статьи: 23.07.2017

Дата принятия статьи: 21.11.2017
\end{abstract}

\section{ДЕМОГРАФИЧЕСКИЕ ПОСЛЕДСТВИЯ СТАЛИНГРАДСКОЙ БИТВЫ ${ }^{1}$}

Евгений Федорович Кринко

Южный научный центр РАН, г. Ростов-на-Дону, Российская Федерация 


\author{
Максим Валерьевич Медведев \\ Южный научный центр РАН, г. Ростов-на-Дону, Российская Федерация,
}

\begin{abstract}
Аннотация. Первые сведения о потерях Красной Армии и вермахта в битве за Сталинград, гибели мирного населения Сталинградской области в период нацистской оккупации были опубликованы еще в годы Великой Отечественной войны. В последующем многие авторы исследовали данные вопросы. В начале 1990-х гг. советские потери подсчитала группа специалистов Генерального штаба под руководством генерал-полковника Г.Ф. Кривошеева. Однако существуют и альтернативные точки зрения по данному вопросу. В целом, демографические последствия Сталинградской битвы как комплексная научная проблема недостаточно изучены.

Авторы статьи рассматривают различные виды потерь, называют главные войсковые объединения и соединения, принимавшие участие в боях за Сталинград, указывают их численность. Отдельно рассматриваются потери среди гражданского населения. По самым скромным подсчетам, в ходе Сталинградской битвы военные потери с обеих сторон составили не менее 2-2,5 млн человек. Население Сталинградской области сократилось вследствие эвакуации, боевых действий и оккупации более чем на 0,5 млн человек, или почти на четверть. Массовые потери вели к значительным деформациям в демографической структуре населения Сталинградской и соседних областей. Особенно резко снизилась доля мужчин трудоспособного возраста. Эти деформации на многие десятилетия определили неблагоприятные тенденции в демографическом развитии региона.
\end{abstract}

Е.Ф. Кринко является автором вводного раздела, в котором раскрываются основные виды потерь и соотношение сил к началу Сталинградской битвы, а также выводов, в которых обобщаются результаты исследования.

М.В. Медведев является автором основной части, в которой раскрываются конкретные виды военных и гражданских потерь, понесенных в результате Сталинградской битвы.

Ключевые слова: Великая Отечественная война, битва за Сталинград, Сталинградская область, Красная Армия, вермахт, демографические процессы.

Цитирование. Кринко Е. Ф., Медведев М. В. Демографические последствия Сталинградской битвы // Вестник Волгоградского государственного университета. Серия 4, История. Регионоведение. Международные отношения. - 2018. - Т. 23, № 1. - C. 91-104. - DOI: https://doi.org/10.15688/jvolsu4.2018.1.9

Сталинградская битва - одно из важнейших сражений Великой Отечественной войны - всегда вызывала пристальное внимание отечественных $[8 ; 19 ; 24 ; 29,37$ и др.] и зарубежных [2; 16;28; 35 и др.] исследователей. Данной теме посвящены не только десятки обобщающих и специальных трудов, но и фундаментальное энциклопедическое издание [36]. Общее количество публикаций заметно превышает историографию большинства других сражений Великой Отечественной войны $[1$, c. $438 ; 14$, с. $22-23 ; 27$, с. $143-148$ и др.]. Не раз исследователи обращались и к демографическим последствиям Сталинградской битвы. Сведения о потерях противника в боях под Сталинградом регулярно приводились в сводках Совинформбюро. В частности, в сообщении от 2 февраля 1943 г. отмечалось, что «за время боев с 10 января по 2 февраля наши войска взяли в плен 91000 немецких солдат и офицеров», в том числе 24 генерала и более 2500 офицеров [32, с. 88-89]. Впоследствии эти данные с уточнениями приводились во многих отечественных и зарубежных исследованиях. Так, Б.Г. Лидделл-Гарт писал: «За три недели русского наступления было взято в плен 92 тыс. немецких солдат и офицеров, а общие потери немецких войск составили примерно в три раза большую цифру. Среди сдавшихся в плен было 24 генерала» [16, с. 113].

Выступая 6 ноября 1943 г. с докладом, посвященным 26-й годовщине Октябрьской революции, И.В. Сталин заявил, что по окончании Сталинградской битвы было подобрано и захоронено 147,2 тыс. немецких солдат и офицеров и 46,7 тыс. советских солдат и офицеров $[34$, с. 113$]$. Это один из примеров того, как в годы войны потери противника преувеличивались, а собственные приуменьшались в пропагандистских целях [15, с. 220-223]. Также поступали и в других воюющих государствах. Нередко преувеличивались потери противника в боевых донесения и других военных документах. В начале 1990-х гг. советские потери в Сталинградской битве подсчитала группа специалистов Генерального шта- 
ба под руководством генерал-полковника Г.Ф. Кривошеева [10]. В большинстве зарубежных исследований сведения по данному вопросу фрагментарны, порой неточны, прежде всего из-за отсутствия у авторов возможностей работы в фондах Центрального архива Министерства обороны Российской Федерации.

В 1942 г. была создана Чрезвычайная государственная комиссия по установлению и расследованию злодеяний немецко-фашистских захватчиков и их сообщников и причиненного ими ущерба гражданам, колхозам, общественным организациям, государственным предприятиям и учреждениям СССР (далееЧГК СССР). Подсчетом потерь гражданского населения в период нацистской оккупации, расследованием преступлений, совершенных захватчиками и их пособниками по отношению к мирным жителям и советским военнопленным непосредственно на территории Сталинградской области, занималась Сталинградская областная комиссия содействия работе ЧГК СССР.

Обобщающие сведения о потерях населения приводят различные исследователи. Наиболее полно трагедия гражданского населения Сталинграда и Сталинградской области раскрыта в кандидатской диссертации и монографии Т.А. Павловой $[21 ; 23]$. Однако в целом демографические последствия Сталинградской битвы представляются недостаточно изученными.

В первую очередь, необходимо определить, какие именно виды потерь требуется учитывать, а также какие войсковые объединения и соединения принимали участие в боях, какова была их численность, тем более, что они не раз меняли свой состав и наименования. Обычно разделяют потери среди комбатантов - военнослужащих, непосредственно участвовавших в боевых действиях, и потери среди гражданского населения, которые могут быть охарактеризованы как жертвы войны. Выделяют также безвозвратные и временные потери. К безвозвратным относят погибших в боях, пропавших на фронте без вести, умерших от ран, болезней и по другим причинам на поле боя и в лечебных учреждениях, попавших в плен. По своему характеру они распределяются на боевые и небоевые.
Боевые - убитые на поле боя, умершие от ран на этапах санитарной эвакуации и в госпиталях, пропавшие без вести в условиях боя и попавшие в плен. К небоевым отнесены потери, не связанные с непосредственным выполнением боевого задания - погибшие при неосторожном обращении с оружием, в авариях, катастрофах и в результате других происшествий, умершие от болезни в лечебных учреждениях и на дому, покончившие жизнь самоубийством, расстрелянные по приговору военных трибуналов за воинские и уголовные преступления. К временным или санитарным потерям относят раненых, контуженых, больных и обмороженных военнослужащих, утративших боеспособность и эвакуированных из района боевых действий в лечебные учреждения не менее чем на одни сутки. Военнослужащие, получившие легкие ранения, травмы или заболевания, не повлекшие за собой выбытие из строя, в число санитарных потерь не включались.

В Сталинградской битве участвовали войска нацистской Германии и ее союзников Италии, Румынии, Хорватии. Кроме того, в составе частей вермахта было немало советских граждан - коллаборационистов, по тем или иным причинам перешедших на сторону врага. Против них сражались военнослужащие Красной Армии и Военно-морского флота СССР, войска НКВД СССР, добровольческие формирования и партизанские отряды.

Началом Сталинградской битвы считается наступление группы армий «Б» (командующий - генерал-полковник М. Вейхс) 17 июля в большой излучине Дона, прикрывавшей с фланга продвижение группы армий «А» (командующий - генерал-фельдмаршал В. Лист) на Кавказ. В состав группы армий «Б» входили 6-я немецкая, с 28 июля - 8-я итальянская, с 31 июля - 4-я танковая, с 16 сентября - 3-я, а с 16 октября - 4-я румынские армии. Численность 6-й армии первоначально составляла около 430 тыс. чел. [12, с. 56]. Позже она существенно возросла за счет союзников - 230,9 тыс. румын и 229 тыс. итальянцев. К северу от итальянцев, занимавших левый фланг группы армий «Б», располагались позиции 2-й венгерской армии, насчитывавшей 209 тыс. чел. [26, с. 88-89]. В боях в Сталинграде также участвовал 
369-й Хорватский пехотный полк, насчитывавший 3895 чел. [18, с. 385].

Вражеской группировке противостояли войска Сталинградского фронта (командующие - Маршал Советского Союза С.К. Тимошенко, с 23 июля - генерал-лейтенант В.Н. Гордов). Он был образован 12 июля 1942 г. на базе упраздненного Юго-Западного фронта и включал первоначально 21-ю общевойсковую и 8-ю воздушную армии, переданные из резерва Ставки Верховного Главнокомандования 62, 63 и 64-ю армии. В последующем в его состав входили 1-я и 2-я гвардейские, 5-я ударная, 28, 38, 51, 57, 66-я армии, 1-я и 4-я танковые, 16-я воздушная армии, 13, 22 и 23-й танковые корпуса. В оперативном подчинении фронта находились Волжская военная флотилия и Сталинградский корпусной район ПВО. Многие соединения Сталинградского фронта были ослаблены в предыдущих боях. По неполным данным, к 17 июля боевой состав четырех армий -21 , 28, 38 и 57-й - составлял всего 30705 чел. [5, л. 48-50] Общая численность войск фронта первоначально составляла 386365 чел. [12, с. 6].

17 июля начались бои авангардов 6-й армии вермахта (командующий - генерал танковых войск Ф. Паулюс) с передовыми частями 62-й и 64-й армий Сталинградского фронта в большой излучине Дона. В данной связи в энциклопедии «Сталинградская битва» справедливо отмечается: «Период с 17.7 по 10.8.1942 вошел в историю Сталинградской битвы как период оборонительных сражений на дальних подступах к Сталинграду. Насколько правомерно такое утверждение?» Авторы данной работы полагают, что «правильнее назвать эти действия встречным сражением», поскольку советские соединения «не имели в то время четких указаний относительно рубежей обороны и решали задачи наступательного характера» [36, с. 270]. В историографии отмечается необходимость специального изучения боев в большой излучине Дона. Данной теме было посвящено исследование, выполненное под руководством академика Г.Г. Матишова [6].

7 августа из Сталинградского фронта был выделен Юго-Восточный фронт (командующий - генерал-полковник А.И. Еременко), в который вошли 51, 57, 64-я, позже - 1-я гвар- дейская, 28-я, 62-я общевойсковые и 8-я воздушная армии. В составе Сталинградского фронта остались 21, 62, 63-я армии, 4-я танковая и 16-я воздушная армии. 9 августа Сталинградский фронт был в оперативном отношении подчинен командующему войсками Юго-Восточного фронта. 28 сентября Ставка ВГК упразднила единое командование Юго-Восточного и Сталинградского фронтов, 30 сентября переименовала Сталинградский фронт в Донской (командующий - генерал-лейтенант К.К. Рокоссовский), а Юго-Восточный - в Сталинградский. В состав нового Сталинградского фронта вошли 28, 51, 62, 64-я армии и 8-я воздушная армия, в декабре 1942 г. 2-я гвардейская и 5-я ударная армии. В состав Донского фронта были включены 1-я гвардейская, 21, 24, 63, 66-я армии, 4-я танковая и 16-я воздушная армии, с 22 октября - 65-я, а с 1 января 1943 г. - 57, 62 и 64-я армии.

Всего в состав трех фронтов в период оборонительных боев под Сталинградом входили 12 армий, в том числе 2 танковые. К 19 ноября численность войск Донского фронта составила 284373 чел., Сталинградского - 367943 чел. [11, с. 281-282]. 25 октября 1942 г. был воссоздан Юго-Западный фронт (командующий - генерал-лейтенант, с 7 декабря - генерал-полковник Н.Ф. Ватутин). В него вошли $21,63,5$-я танковая и 17-я воздушная армии, позже - 1-я и 3-я гвардейские, 5-я ударная армии. Общая численность войск фронта составила 389902 чел. [11, с. 277].

В ходе кровопролитных боев на подступах к Сталинграду и в самом городе советские части и соединения понесли тяжелые потери. Численность 62-й армии, несмотря на постоянное пополнение личного состава, в сентябре 1942 г. не превышала 40 тыс. чел. [19, c. 39]. О численности отдельных соединений Юго-Восточного фронта в начале сентября свидетельствуют данные таблицы 1.

Ценой больших потерь наступление противника удалось приостановить уже в Сталинграде. Так, 71-я пехотная дивизия вермахта в конце августа 1942 г. сравнительно быстро овладела Калачом. Но уже 3 сентября при прорыве внутреннего кольца обороны Сталинграда столкнулась с мощным сопротивлением, потеряв за сутки более 200 чел. [9, с. 312 313]. В отдельных случаях потери противни- 
ка превышали советские. Так, 23-й танковый корпус при отражении наступления противника 13 сентября потерял 250 чел. убитыми и ранеными. При этом общие потери противника, согласно боевым донесениям, составили до 1260 чел. [19, с. 44-45].

\section{Численность отдельных соединений Юго-Восточного фронта} на 7 сентября 1942 г. [4, л. 49-50]

\begin{tabular}{|c|c|c|}
\hline $\begin{array}{c}\text { № } \\
\text { П/П } \\
\end{array}$ & Соединения & чел. \\
\hline 1 & 399-я стрелковая дивизия & 195 \\
\hline 2 & 112-я стрелковая дивизия & 56 \\
\hline 3 & 35-я стрелковая дивизия & 1000 \\
\hline 4 & 87-я стрелковая дивизия & 180 \\
\hline 5 & 157-я стрелковая дивизия & 180 \\
\hline 6 & 126-я стрелковая дивизия & 1000 \\
\hline 7 & 2-я мотострелковая бригада & 112 \\
\hline 8 & 134-я морская бригада & 500 \\
\hline 9 & 66-я морская бригада & 400 \\
\hline 10 & 27-я танковая бригада & 30 \\
\hline 11 & 99-я танковая бригада & 120 \\
\hline \multicolumn{2}{|r|}{ Bсего } & 3593 \\
\hline
\end{tabular}

Однако в целом в этот период советские потери были намного выше, чем у противника. К 12 сентября все стрелковые дивизии Сталинградского фронта потеряли до 4 тыс. чел. каждая [24, с. 14-15]. Санитарные потери советских войск в боях за Сталинград в конце сентября составляли около 2-3 тыс. чел. в сутки [3, л. 208-211]. Попытки прорыва 1-й гвардейской, 24-й и 66-й армий севернее Сталинграда в сентябре 1942 г. привели к потерям в 120 тыс. человек. Потери противостоявших им 16-й танковой, 76-й пехотной, 3-й и 60-й моторизованных дивизий вермахта за сентябрь 1942 г. составили всего 10 тыс. чел. [12, с. 9]. В конце октября 1942 г. при неудачных попытках прорвать немецкую оборону стрелковые дивизии Донского фронта потеряли в среднем по 4-5 тыс. человек. В результате 2 ноября были расформированы $62,207,212,221,231,292$ и 316-я стрелковые дивизии как понесшие большие потери и обладавшие «слабыми боевыми традициями» [24, с. 25-26].

В городских боях потери частей вермахта возросли и уже не покрывались пополнением из Германии. Общие потери групп армий «А» и «Б» в третьем квартале 1942 г. составили 282600 военнослужащих, а пополне- ние - только 140750 человек. В IV квартале потери на юге составили 199700 чел., а в качестве пополнения из армии резерва поступило лишь 89600 человек. В конце декабря некомплект личного состава в среднем превышал 4 тыс. чел. в дивизии [20, с. 350, 354]. Нехватку личного состава стали покрывать за счет «хиви» (добровольных помощников) из советских граждан - в основном военнопленных, содержавшихся в лагерях в тяжелейших условиях. В 71-й и 76-й пехотных дивизиях служили по 8 тыс. коллаборационистов - почти половина их личного состава. Точных данных об общей численности бывших советских граждан во вспомогательных частях 6-й армии Паулюса нет, отдельные авторы называют цифpy 50-70 тыс. человек [2, с. 198 и др.].

Согласно подсчетам группы Г.Ф. Кривошеева, в Сталинградской оборонительной операции с 17 июля по 18 ноября 1942 г. общие потери Сталинградского фронта составили 409990 чел., в том числе 194685 чел. - безвозвратные, 215305 чел. - санитарные, среднесуточные - 3280 человек. Общие потери Юго-Восточного фронта - 173076 чел., в том числе 110636 чел. - безвозвратные, 62440 чел. - санитарные, среднесуточные 3147 человек. Общие потери Донского фронта - 59969 чел., в том числе 18028 чел. - безвозвратные, 41941 чел. - санитарные, среднесуточные - 1200 человек. Общие потери Волжской военной флотилии - 807 чел., в том числе 507 чел. - безвозвратные, 300 чел. - санитарные, среднесуточные - 7 человек. Общие потери советских войск в Сталинградской оборонительной операции составили 643842 чел., в том числе 323856 чел. (59,2 \% от общей численности потерь) - безвозвратные, 319986 чел. - санитарные, среднесуточные - 5151 человек [7, с. 109].

А.В. Исаев указывает, что общие потери 6-й армии вермахта к 18 ноября 1942 г. составили около 144 тыс. чел., в том числе безвозвратные потери - 24 тыс. чел. 4-я танковая армия потеряла с 1 августа по 18 ноября 1942 г. около 20 тыс. чел., в том числе 4,3 тыс. чел. безвозвратно. Потери 3-й румынской армии составили около 13 тыс. человек. Согласно его подсчетам, соотношение безвозвратных потерь вермахта и советских войск в оборонительный период Сталинградской битвы со- 
ставляет один к десяти, а общих потерь - примерно один к трем. Это объясняется не только ошибками советских полководцев или отсутствием боевого опыта у принявших на себя первый удар резервных армий, но и превосходством противника в тяжелой артиллерии $[12$, c. 10]. Эти цифры значительно расходятся с традиционными для отечественной историографии утверждениями о потерях вермахтом около 700 тыс. чел. убитыми и ранеными $[36$, c. 413$]$.

Выдержав натиск противника, истощившего свои силы в городских боях, 19-20 ноября войска Донского, Юго-Западного и Сталинградского фронтов перешли в контрнаступление. В ходе операции «Уран» 23 ноября группировка противника в междуречье Волги и Дона была окружена. С 12 по 24 декабря 1942 г. войска Сталинградского фронта в ходе Котельниковской операции не позволили противнику деблокировать окруженную группировку врага. Войска Юго-Западного фронта в декабре 1942 г. при содействии Воронежского фронта провели Среднедонскую операцию, окончательно сорвав план деблокады группировки Паулюса. 1 января 1943 г. Сталинградский фронт был переименован в Южный. Донской фронт с 10 января по 2 февраля 1943 г. провел операцию «Кольцо», в результате которой окруженная группировка противника была разгромлена, а ее остатки капитулировали.

В Сталинградской наступательной операции с 18 ноября 1942 г. по 2 февраля 1943 г. потери Юго-Западного фронта составили 212692 чел., в том числе 64649 чел. - безвозвратные, 148043 чел. - санитарные, 4946 чел. - среднесуточные. Общие потери Донского фронта - 169925 чел., в том числе 123560 чел. - безвозвратные, 46365 чел. санитарные, среднесуточные - 2236 человек. Общие потери Сталинградского фронта 101630 чел., в том числе 43552 чел. - безвозвратные, 58078 чел. - санитарные, среднесуточные - 2363 человек. Общие потери 6-й армии и 2-й воздушной армии Воронежского фронта - 1488 чел., в том числе 304 чел. безвозвратные, 1184 чел. - санитарные, 496 чел. - среднесуточные. Общие потери Волжской военной флотилии - 42 чел., в том числе 15 чел. - безвозвратные, 27 чел. - санитарные, среднесуточные - 0,5 человека.
Общие потери советских войск в Сталинградской наступательной операции составили 485777 чел., в том числе 154885 чел. (13,5\% от общей численности потерь) - безвозвратные, 330892 чел. - санитарные, среднесуточные - 6392 человек [7, с. 114].

Общие потери РККА и ВМФ СССР в Сталинградской битве, согласно приводимым расчетам, составляют 1129619 чел., в том числе безвозвратные - 478741 человек. Очень высока была численность пропавших без вести и попавших в плен военнослужащих, особенно в первый период боев. Только на Сталинградском (1-го формирования) и Донском фронтах их насчитывалось 299130 чел., или $37,77 \%$ от общих потерь за 218 суток боев [7, с. 221].

Приводимые данные рассчитаны только на основе потерь РККА и ВМФ СССР и не учитывают потери войск НКВД и добровольческих формирований, которые, впрочем, принципиально не меняют общий порядок потерь. В Сталинградской битве участвовали 10 -я стрелковая дивизия НКВД, а также 91-й полк НКВД по охране железных дорог, 178-й полк НКВД по охране особо важных промышленных предприятий, 249-й полк конвойных войск НКВД, 73-й отдельный бронепоезд, 2, 9, 79 и 98-й пограничные полки. К октябрю 1942 г. из 7,6 тыс. чел. в 10-й стрелковой дивизии НКВД осталось чуть более 200 чел., выведенных на переформирование. Соответствующие потери понесли и другие части войск НКВД.

Самое крупное соединение, созданное в Сталинграде на добровольческой основе, Сталинградская стрелковая дивизия народного ополчения не являлась боевым соединением и в основном играла роль учебно-запасного центра по подготовке резервов для действующей армии. В оборонительных боях за Сталинград приняли участие отдельные отряды народного ополчения вместе с другими добровольческими формированиями - рабочими отрядами, истребительными батальонами, частями местной противовоздушной обороны $[36$, с. 395,562$]$. Уступая в опыте и вооружении регулярным войскам, они понесли немалые потери, достигнувшие нескольких тысяч человек. В период оккупации в захваченных противником районах Сталинградской области действовали 11 партизанских отрядов и 
групп общей численностью в 186 человек. Погибли в боях и были казнены оккупантами около 100 человек [36, с. 435-436].

Таким образом, общие потери советских войск в ходе Сталинградской битвы можно определить в 1 140-1 150 тыс. чел. По другим данным, потери фронтов сталинградского направления составили 1347214 чел., в том числе 674990 чел. - безвозвратные [24, с. 118]. С учетом потерь войск НКВД и добровольческих формирований они могли составлять $1360-1370$ тыс. человек.

На еще более высоких цифрах потерь настаивает Б.В. Соколов. Он говорит о более 2 млн чел., ссылаясь на воспоминания бывшего директора Музея обороны ЦарицынаСталинграда А.М. Бородина, к которому обратился Е.В. Вучетич с просьбой составить полный список погибших для увековечивания на Мамаевом кургане: «Кинулся в Подольский архив, в Бюро потерь Генштаба Минобороны. Генерал-майор, руководивший тогда этим Бюро, рассказал, что такую задачу им уже ставил секретарь ЦК Козлов. После года работы он вызвал генерала и спросил о результатах. Когда узнал, что насчитали уже 2 млн погибших, а работы еще на много месяцев, сказал: “Хватит!” И работу прекратили. Тогда я спросил этого генерала: “Так сколько же мы потеряли под Сталинградом, хотя бы примерно?” - “Я вам не скажу”» (цит. по: [31]).

Однако подобные оценки вызывают критику других авторов, отрицающих их научную состоятельность: «Преднамеренное завышение потерь сов. войск является одним из испытанных средств политизированных средств массовой информации, заинтересованных во внедрении в общественное сознание идеи о принципиальной порочности сов. “тоталитарной” системы» [36, с. 272]. В данной связи показательны приводимые разными авторами сведения о количестве расстрелянных трибуналами советских военнослужащих. Э. Бивор указывает, что за время Сталинградской битвы 13,5 тыс. советских военнослужащих были приговорены военным трибуналом к смертной казни [2, с. 180]. Это выглядит преувеличением, так как с 1 августа по 15 октября 1942 г., в самый критический период битвы, заградительные отряды Донского фронта задержали 36109 военнослужащих, сбежав- ших с передовой. Из числа задержанных были арестованы 736 чел., расстреляны 433 чел., направлены в штрафные роты и батальоны 1089 чел., остальные 32933 чел. возвращены в свои части и на пересыльные пункты. Заградительные отряды Сталинградского фронта за тот же период задержали 15649 чел., арестовали 244 чел., расстреляли 278 чел., направили в штрафные роты и батальоны 262 чел., вернули в свои части и на пересыльные пункты 14833 человека [38, с. 222].

Б. Мюллер-Гиллебранд указывает, что потери 6-й армии с момента ее окружения до капитуляции составили 209,5 тыс. человек. Общая убыль в личном составе в группах армий «А» и «Б» с ноября 1942 г. про февраль 1943 г. превысила пополнение на 162 тыс. человек [20, с. 373-374]. Однако первый квартирмейстер штаба 6-й армии В. фон Куновский, оказавшись в советском плену, утверждал, что к 22 ноября 1942 г. общая численность окруженной группировки составляла 248 тыс. чел., включая до 1 тыс. чел. в строительной организации Тодта, до 7 тыс. чел. в 9-й зенитной дивизии, до 20 тыс. «добровольцев» из советских военнопленных, до 7 тыс. чел. из частей, обслуживающих ВВС. К 10 января 1943 г. было потеряно до 10 тыс. убитыми и вывезено на самолетах 25 тыс. раненых и больных [37, с. 550]. По советским данным, только в ходе операции «Кольцо» было уничтожено 147 200, взято в плен 91545 солдат и офицеров противника [30, с. 520]. Большинство оказавшихся в плену умерло от истощения, дизентерии и других болезней. К этим цифрам нужно прибавить потери немецких войск на начальной фазе операции «Уран», в Котельниковской и Среднедонской операциях.

Общие потери румынских войск в боях на Дону и Волге составили 158850 человек. Венгрия потеряла 96 тыс. чел., в том числе 42 тыс. погибшими, умершими от ран, пропавшими без вести, 28 тыс. ранеными, 26 тыс. пленными. Итальянская армия с 11 декабря 1942 г. по 31 января 1943 г. потеряла 84830 чел. убитыми, пропавшими без вести и пленными, 29690 - ранеными и обмороженными, что составило $60 \%$ офицерского и $49 \%$ рядового состава до начала наступления [26, с. 93-94]. Хорватский полк был практически полностью уничтожен. Точные потери советских колла- 
борационистов не известны. К моменту окружения только в 6-й полевой армии их насчитывалось 19,3 тыс. человек [11, с. 409]. По воспоминаниям фронтовиков, в плен их брали редко [9, с. 127]. Всего в ходе Сталинградской битвы было нанесено поражение 48 дивизиям и 3 бригадам противника. Общие потери вермахта и его союзников в период Сталинградской наступательной операции оцениваются в 800 тыс. человек [36, с. 560]. Это количество представляется завышенным, как и общее количество потерь противника в 1,5 млн человек [36, с. 553]. Анализ доступных свидетельств позволяет считать, что потери вермахта и его союзников в Сталинградской битве составили не более 880 тыс. человек [6, c. 392]. Тем не менее даже эта цифра потерь свидетельствует о том, что соотношение общих и безвозвратных потерь в период контрнаступления под Сталинградом существенно изменилось в пользу советских войск.

Значительными были и потери гражданского населения вследствие Сталинградской битвы. Населенные пункты в зоне боевых действий и прилегающих районах подвергались регулярным бомбардировкам авиации и артиллерийским обстрелам. Особенно варварские бомбардировки пришлось испытать Сталинграду. Только в результате бомбардировок с 23 по 29 августа 1942 г. погибли 71 тыс. мирных жителей, не менее 142 тыс. чел. получили ра- нения разной степени тяжести, контузии, травмы [23, с. 185-186].

Следует учесть, что к лету 1942 г. численность жителей Сталинградской области значительно сократилась вследствие мобилизации на фронт и эвакуации. В то же время Сталинградская область стала местом приема эвакуированных из западных регионов граждан. С 29 июня 1941 г. по март 1942 г. через Сталинградский пункт эвакуирования прошли 441 тыс. человек. Более 200 тыс. чел. были направлены в районы области. В условиях приближения войск противника началась эвакуация жителей Сталинградской области. С 16 по 27 июля за Волгу было вывезено свыше 100 тыс. чел. [36, с. 698]. В дальнейшем выселению и отселению подвергались жители прифронтовых территорий. Но подавляющее большинство жителей сельских районов (свыше 80 \%) не было эвакуировано и осталось на территории, ставшей зоной боевых действий, а затем оккупированной противником.

В ходе немецкого наступления с середины июля до начала сентября 1942 г. были захвачены 14 из 74 сельских районов Сталинградской области [39]. Оккупация продолжалась от 3,5 до 5,5 месяцев до советского контрнаступления в конце ноября - начале января 1943 г. и сопровождалась массовыми репрессиями против населения (табл. 2).

Таблища 2

Установленные злодеяния, совершенные оккупантами в отношении жителей сельских районов Сталинградской области [33, л. 3 об.-4]

\begin{tabular}{|l|r|r|r|c|}
\hline \multicolumn{1}{|c|}{ Районы } & $\begin{array}{c}\text { Расстреляно, } \\
\text { повешено }\end{array}$ & $\begin{array}{c}\text { Случаев } \\
\text { насилия }\end{array}$ & Угнано & $\begin{array}{c}\text { Погибло } \\
\text { от бомбардировок } \\
\text { и обстрелов }\end{array}$ \\
\hline Клетский & 7 & 50 & 8 & - \\
\hline Сиротинский & 14 & 74 & 3327 & 23 \\
\hline Перелазовский & 4 & 5 & - & - \\
\hline Чернышковский & 9 & 18 & - & - \\
\hline Тормосиновский & 57 & 88 & - & - \\
\hline Кагановичский & 2 & 115 & - & - \\
\hline Нижнечирский & 301 & 73 & 800 & - \\
\hline Калачевский & 32 & 23 & - & - \\
\hline Серафимовичский & 40 & 585 & 5000 & - \\
\hline Котельниковский & 48 & 14 & 125 & - \\
\hline Ворошиловский & 411 & 95 & 36 & - \\
\hline Верхнекурмоярский & 22 & 31 & 8 & - \\
\hline Красноармейский & - & 6 & - & 43 \\
\hline Городищенский & 38 & 38 & 8379 & - \\
\hline \multicolumn{1}{|c|}{ Итого } & 985 & 1215 & 17683 & \\
\hline
\end{tabular}


По мнению Т.А. Павловой, эти цифры являются неполными. Она указывает, что в период оккупации были повешены и расстреляны 1852 чел., 1598 чел. подвергались пыткам. Более 50 тыс. жителей сельских районов погибли вследствие боевых действий [23, с. 550].

Еще большие потери понесло население областного центра. До 23 августа, когда начались массовые бомбардировки Сталинграда, из него было вывезено 100 тыс. чел., в том числе не более 35-40 тыс. местных жителей. Принятые с запозданием решения об эвакуации не могли быть полностью выполнены. К 14 ноября из Сталинграда было эвакуировано 348,8 тыс. мирных граждан, или 49,1\% населения, находившегося в нем 23 августа [23, с. 554]. Обобщающие данные о потерях, понесенных сталинградцами, представлены в итоговом отчете Сталинградской комиссии содействия работе ЧГК СССР (см. табл. 3).

Приводимые данные также считаются неполными. Из 200 тыс. чел., оказавшихся в зоне немецкой оккупации, были депортированы 170 тыс. жителей. 75 тыс. чел. вывезли на принудительную работу в Германию и другие страны, из них 45 тыс. чел. вернулись назад. Вследствие этого Т.А. Павлова полагает, что около 30 тыс. чел. погибли в ходе перевозки и на принудительных работах. Однако невозвращение может объясняться не только гибелью, но и нежеланием репатриантов. В любом случае, указанные 30 тыс. чел. относятся к демографическому ущербу населения Сталинградской области. Остальные 95 тыс. чел. были заключены в лагеря для военнопленных, расселены на оккупированной терри- тории Сталинградской и Ростовской областей или на Украине. Назад в 1945 г. вернулись 44098 чел., а свыше 50 тыс. чел. Т.А. Павлова считает погибшими. Всего за пределами $\mathrm{CCCP,} \mathrm{на} \mathrm{оккупированной} \mathrm{территории} \mathrm{и} \mathrm{в} \mathrm{са-}$ мом Сталинграде от бомбардировок и обстрелов погибли более 81 тыс. чел. [23, с. 507508]. По подсчетам Т.А. Павловой, общие безвозвратные потери населения Сталинграда за время битвы превысили 185 тыс. человек. Из 710 тыс. чел., находившихся в городе 23 августа 1942 г., за время массированной бомбардировки, боевых действий и оккупации погибло не менее $26 \%$ его жителей [23, с. 554].

Вследствие Сталинградской битвы значительно пострадали и прилегавшие к Сталинградской области районы Ростовской и Ворошиловградской (в настоящее время Луганской) областей. Во всех оккупированных районах происходили расправы немецких преступников над мирными жителями. Bсего за период оккупации в Ростовской области были повешены, расстреляны, замучены, умерли от голода и были отправлены на трудовые работы в Германию 182021 чел. [25, л. 1-3], в Ворошиловградской области 170 тыс. челвек [17].

Крайней жестокостью отличалось отношение нацистов к советским военнопленным. Только на территории Сталинградской области действовали 47 лагерей для советских военнопленных [23, с. 325]. По неполным данным, в них было уничтожено около 8 тыс. красноармейцев и мирных граждан. На оккупированной территории Ростовской области было уничтожено не менее 21 тыс. советских военнопленных [25, л. 10].

Таблииа 3

\section{Установленные злодеяния, совершенные оккупантами в отношении жителей районов города Сталинграда [33, л. 4]}

\begin{tabular}{|l|c|c|c|c|}
\hline \multicolumn{1}{|c|}{ Районы } & $\begin{array}{c}\text { Расстреляно, } \\
\text { повешено }\end{array}$ & $\begin{array}{c}\text { Случаев } \\
\text { насилия }\end{array}$ & Угнано & $\begin{array}{c}\text { Погибло } \\
\text { от бомбардировок } \\
\text { и обстрелов }\end{array}$ \\
\hline Тракторозаводский & 3 & 3 & 1499 & 1903 \\
\hline Баррикадный & - & - & 1682 & 5252 \\
\hline Краснооктябрьский & 2 & - & 2520 & 5041 \\
\hline Дзержинский & 654 & 309 & 13000 & 10737 \\
\hline Ерманский & 202 & 71 & 1106 & 11727 \\
\hline Ворошиловский & 6 & - & 23008 & 7555 \\
\hline Кировский & - & - & 1692 & 539 \\
\hline Красноармейский & - & - & 2034 & - \\
\hline \multicolumn{1}{r|}{ Итого } & 867 & 383 & 46541 & 42754 \\
\hline
\end{tabular}


Таким образом, Сталинградская битва стала одним из самых кровопролитных сражений. По самым скромным подсчетам, суммарные военные потери с обеих сторон составили не менее 2-2,5 млн чел., или более 10 \% всех военных потерь СССР и Германии, а также большую часть потерь союзников Германии - Италии, Венгрии, Румынии и Хорватии в годы войны.

По итогам всесоюзной переписи населения 1939 г., в Сталинградской области проживало 2288129 человек. Всего за вторую половину 1941 г. - первую половину 1942 г. из Сталинградской области на фронт было мобилизовано 434684 чел. [23, с. 25] - почти $19 \%$ ее населения. После освобождения от оккупации зимой 1943 г. насчитывалось 1 292,3 тыс. жителей. Сокращение населения вследствие эвакуации, боевых действий и оккупации составило 555,7 тыс. чел., или почти $24,3 \%$. Прямые потери от нацистской оккупации в Сталинградской области были не менее 235 тыс. чел., в прилегавших к ней Ростовской и Ворошиловградской областях еще порядка 340 тыс. человек. Общий демографический ущерб Сталинградской битвы можно оценить в 2,5-3 млн чел., что позволяет считать ее настоящей демографической катастрофой.

Негативные демографические последствия Сталинградской битвы продолжали сказываться и после ее окончания. В результате интенсивных боевых действий хозяйство региона подверглось сильнейшим разрушениям, следствием чего стали недоедание и голод для значительной части жителей. Например, посев озимых под урожай 1943 г., произведенный в период оккупации, в Сталинградской области составил всего 43,6 \% посева под урожай 1941 г. [13, с. 222]. На состоянии здоровья жителей сказывались перенесенные физические и психологические травмы, заболевания, стрессы, а также правовая дискриминация по отношению к тем из них, которые находилась на оккупированной территории или были вывезены на работу в Германию.

Массовые потери вели к значительным деформациям в демографической структуре населения Сталинградской и соседних с нею областей. Особенно резко снизилась доля мужчин трудоспособного возраста. Если до оккупации на 100 мужчин в возрасте от 16 до 55 лет в Сталинградской области приходилось 109 женщин того же возраста, а в Ростовской -108 , то после освобождения эти показатели составляли соответственно 298 и 248 [13, c. 224]. Деформации в половозрастной структуре на многие десятилетия определили крайне неблагоприятные тенденции в демографическом развитии региона в целом [21, с. 59]. Очевидно, что эти вопросы нуждаются в специальном изучении.

\section{ПРИМЕЧАНИЕ}

${ }^{1}$ Статья подготовлена при поддерждке гранта Российского научного фонда (проект № 17-19-01411 «Войны и население юга России XVIII - начале XXI в.: история, демография, антропология»).

\section{СПИСОК ЛИТЕРАТУРЫ}

1. Белов, Д. А. Количественный анализ тенденций развития отечественной историографии Сталинградской битвы / Д. А. Белов // Сталинградская битва в судьбах народов : материалы Междунар. науч.-практ. конф., 2013 г. - Волгоград : Принт, 2013. - C. 438-440.

2. Бивор, Э. Сталинград / Э. Бивор. - Смоленск : Русич, 1999. -445 с.

3. Боевое донесение Военного совета ЮгоВосточного фронта в Ставку ВГК о ходе боевых действий в Сталинграде 28 сентября 1942 г. // ЦАМО. - Ф. 220. - Оп. 451. - Д. 42. - Л. 208-211.

4. Боевое донесение Военного совета ЮгоВосточного фронта в Ставку ВГК о ходе боевых действий в Сталинграде 8 сентября 1942 г. // ЦАМО. Ф. 220. - Оп. 451. - Д. 42. - Л. 49-50.

5. Боевое донесение штаба Сталинградского фронта начальнику оперативного управления Генерального штаба Красной Армии о боевом и численном составе 21-й, 28-й, 38-й и 57-й армий 17 июля 1942 г. // ЦАМО. - Ф. 220. - Оп. 220. - Д. 4. - Л. 48-50.

6. Большая излучина Дона - место решающих сражений Великой Отечественной войны (1942-1943 гг.) / Г. Г. Матишов, В. И. Афанасенко, Е. Ф. Кринко, М. В. Медведев. - Ростов н/Д : Изд-во ЮНЦ РАН, 2016. - $456 \mathrm{c}$.

7. Великая Отечественная без грифа секретности. Книга потерь : Новейшее справочное издание. - М. : Вече, 2010. -384 с.

8. Водолагин, М. А. Сталинград в Великой Отечественной войне (1941-1943 гг.) / М. А. Водолагин. Сталинград: Областноекнигоиздательство, 1949. -256 с. 
9. Вюстер, В. В аду Сталинграда: кровавый кошмар Вермахта / В. Вюстер. - М. : Яуза-Пресс, 2010. $-320 \mathrm{c}$.

10. Гриф секретности снят: Потери Вооруженных Сил СССР в войнах, боевых действиях и военных конфликтах : Статистическое исследование / ред. Г. Ф. Кривошеев. - М. : Воениздат, 1993. - 415 с.

11. Исаев, А. В. Сталинград. За Волгой для нас земли нет / А. В. Исаев. - М. : Эксмо : Яуза, 2008. $448 \mathrm{c}$.

12. Исаев, А. В. Сталинград. Трудное начало / А. В. Исаев // Родина. - 2013. - № 1. - С. 5-10.

13. Колесник, А. Д. РСФСР в Великой Отечественной войне / А. Д. Колесник. - М. : Наука, 1982. $328 \mathrm{c}$.

14. Кринко, Е. Ф. Боевые действия на юге России в 1941-1943 гг. : историографический опыт и перспективы дальнейших исследований / Е. Ф. Кринко // Значение сражений 1941-1943 гг. на юге России в Победе в Великой Отечественной войне : материалы Всерос. науч. конф. (Ростов-на-Дону, 36 июня 2015 г.). - Ростов н/Д : ЮНЦ РАН, 2015. C. $22-27$.

15. Кропачев, С. А. Потери населения СССР в 1937-1945 гг.: масштабы и формы. Отечественная историография / С. А. Кропачев, Е. Ф. Кринко. М. : Рос. полит. энцикл., 2012. -350 с.

16. Лидделл-Гарт, Б. Г. Вторая мировая война / Б. Г. Лидделл-Гарт. - М. : Воениздат, 1976. - 580 с.

17. Луганщина в годы Великой Отечественной войны : Сборник материалов и документов. - Донецк : Донбасс, 1969. - 736 с.

18. Милич, А. Хорватские добровольцы в германском вермахте во Второй мировой войне / А. Милич // Крестовый поход на Россию : сб. ст. М. : Яуза, 2005.- С. 375-402.

19. Мощанский, И. Б. Оборона Сталинграда, 17 июля - 18 ноября 1942 г. / И. Б. Мощанский. М. : БТВ-КНИГА, 2001. - 83 с. - (Серия: Военная летопись - «Сражения и битвы» ; 2001, № 1).

20. Мюллер-Гиллебранд, Б. Сухопутная армия Германии 1933-1945 гг. / Б. Мюллер-Гиллебранд. М. : Изографус : Эксмо, 2002. -800 с.

21. Население России в XX веке : Исторические очерки. В 3 т. Т. 2. 1940-1959. - М. : РОССПЭН, 2001. $-416 \mathrm{c}$.

22. Павлова, Т. А. Гражданское населениеСталинградской области в условиях германской оккупации: июль 1942 г. - февраль 1943 г. : дис. ... канд. ист. наук / Павлова Татьяна Анатольевна. - СПб., 2007. - 245 с.

23. Павлова, Т. А. Засекреченная трагедия: гражданское население в Сталинградской битве / Т. А. Павлова. - Волгоград : Перемена, 2005. -593 с.

24. Панин, А. Сталинград. Цена победы / А. Панин, С. Переслегин. - М. ; СПб. : АСТ: Terra Fantastica, 2005.-331 c.
25. Постановление Ростовской областной комиссии по учету зверств и ущерба причиненного немецко-фашистскими оккупантами гражданам, колхозам, государственным предприятиям, учреждениям и организациям // Центр документации новейшей истории Ростовской области. - Ф. 1886. Оп. 1. - Д. 22.

26. Разгром «нацистского интернационала» на Дону (1942-1943) / Г. Г. Матишов, Е. Ф. Кринко, В. И. Афанасенко, М. В. Медведев // Вестник Южного научного центра РАН. - 2015. - Т. 11, № 2. С. 87-96.

27. Редькина, О. Ю. Изучение истории Сталинградской битвы и восстановления Сталинграда в Волгоградском государственном университете / О. Ю. Редькина // Вестник Волгоградского государственного университета. Серия 4, История. Регионоведение. Международные отношения. 2013. - № 1 (23). - C. 143-148. - DOI: https://doi.org/ 10.15688/jvolsu4.2013.1.23.

28. Робертс, Дж. Победа под Сталинградом. Битва, которая изменила историю / Дж. Робертс. М. : УРСС, Едиториал УРСС, 2003. - 175 с.

29. Самсонов, А. М. Сталинградская битва / А. М. Самсонов. - 4-е изд., испр. и доп. - М. : Наука, 1989. - 629 с.

30. Советская военная энциклопедия. Т. 7. - М. : Воениздат, 1980. - $686 \mathrm{c}$.

31. Соколов, Б. В. Цена победы: Великая Отечественная: неизвестное об известном / Б. В. Соколов. - М. : Московский рабочий, 1991. - 191 с.

32. Сообщения Советского информбюро. Т. 4. Январь - июнь 1943 г. - М. : Совинформбюро, 1944. $-400 \mathrm{c}$.

33. Справка об установленных злодеяниях, совершенных немецко-фашистскими захватчиками и их сообщниками по районам Сталинградской области (без военнопленных) // Центр документации новейшей истории Волгоградской области. Ф. 113. -Оп. 14. - Д. 13.

34. Сталин, И. В. О Великой Отечественной войне Советского Союза / И. В. Сталин. - Изд. 5-е. - М. : Госполитиздат, 1952. - $186 \mathrm{c.}$

35. Сталинград : Событие. Воздействие. Символ : пер. с нем. - М. : Прогресс-Академия, 1995. - 528 с.

36. Сталинградская битва. Июль 1942 - февраль 1943 : энциклопедия / под ред. М. М. Загорулько. 5-е изд., испр. и доп. - Волгоград : Издатель, 2012. $800 \mathrm{c}$.

37. Сталинградская битва: хроника, факты, люди. Кн. вторая. - М. : Олма-Пресс, 2002. - 573 с.

38. Сталинградская эпопея : Материалы НКВД СССР и военной цензуры из Центрального архива ФСБ РФ. - М. : Звонница-МГ, 2000. - 496 с.

39. Krinko, E. F. The Nazi occupation and collaboration in the Stalingrad region (1942-1943) 
/ E. F. Krinko // Journal of International Network Center for Fundamental and Applied Research. - 2016. № 4. -C. 170-178.

\section{REFERENCES}

1. Belov D.A. Kolichestvennyy analiz tendentsiy razvitiya otechestvennoy istoriografii Stalingradskoy bitvy [The Quantitative Analysis of Tendencies of Development of Domestic Historiography of the Battle of Stalingrad]. Stalingradskaya bitva $v$ sudbakh narodov: materialy Mezhdunar. nauch.-prakt. konf., $2013 \mathrm{~g}$. [The Battle of Stalingrad in the Fate of the People. Proceedings of the International Research and Practice Conference, 2013]. Volgograd, Print Publ., 2013, pp. 438-440.

2. Bivor E. Stalingrad. Smolensk, Rusich Publ., 1999. $445 \mathrm{p}$.

3. Boevoe donesenie Voennogo soveta YugoVostochnogo fronta v Stavku VGK o khode boevykh deystviy v Stalingrade 28 sentyabrya 1942 g. [The Military Report of the War Council of the Southeast Front to the Supreme Commander-in-Chief about the Course of Fighting in Stalingrad of September 28, 1942]. Tsentralnyy arkhiv Ministerstva oborony [The Central Archive of the Ministry of Defense], F. 220, Op. 451, D. 42.

4. Boevoe donesenie Voennogo soveta YugoVostochnogo fronta v Stavku VGK o khode boevykh deystviy v Stalingrade 8 sentyabrya 1942 g. [The Military Report of the War Council of the Southeast Front to the Supreme Commander-in-Chief about the Course of Fighting in Stalingrad of September 28, 1942]. Tsentralnyy arkhiv Ministerstva oborony [The Central Archive of the Ministry of Defense], F. 220, Op. 451, D. 42.

5. Boevoe donesenie shtaba Stalingradskogo fronta nachalniku operativnogo upravleniya Generalnogo shtaba Krasnoy Armii o boevom i chislennom sostave 21-y, 28-y, 38-y i 57-y armiy 17 iyulya 1942 g. [The Military Report of the Headquarters of the Stalingrad Front to the Chief of Operative Administration of the General Staff of the Red Army about the Combat Personnel and Their Number of the $21^{\text {st }}, 28^{\text {th }}, 38^{\text {th }}$ and $57^{\text {th }}$ armies of July 17, 1942]. Tsentralnyy arkhiv Ministerstva oborony [The Central Archive of the Ministry of Defense], F. 220, Op. 220, D. 4.

6. Matishov G.G., Afanasenko V.I., Krinko E.F., Medvedev M.V. Bolshaya izluchina Dona - mesto reshayushchikh srazheniy Velikoy Otechestvennoy voyny (1942-1943 gg.) [Large Bend of the Don - the Place of Decisive Battles of the Great Patriotic War (1942-1943)]. Rostov-on-Don, SSC RAS Publ., 2016. $456 \mathrm{p}$.
7. Velikaya Otechestvennaya bez grifa sekretnosti. Kniga poter: Noveyshee spravochnoe izdanie [The Great Patriotic War Without a Secrecy Label. Book of Losses. The Latest Reference Publication]. Moscow, Veche Publ., 2010. 384 p.

8. Vodolagin M.A. Stalingrad v Velikoy Otechestvennoy voyne (1941-1943 gg.) [Stalingrad in the Great Patriotic War (1941-1943)]. Stalingrad, Oblastnoe knigoizd-vo, 1949. 256 p.

9. Vyuster V. V adu Stalingrada: krovavyy koshmar Vermakhta [In the Hell of Stalingrad: Bloody Nightmare of Wehrmacht]. Moscow, Yauza-Press, 2010. $320 \mathrm{p}$.

10. Krivosheev G.F., ed. Grif sekretnosti snyat: Poteri Vooruzhennykh Sil SSSR v voynakh, boevykh deystviyakh i voennykh konfliktakh: Statisticheskoe issledovanie [The Secrecy Label Is Removed: Losses of Armed Forces of the USSR in Wars, Fighting and Military Conflicts: A Statistical Research]. Moscow, Voenizdat Publ., 1993. 415 p.

11. Isaev A.V. Stalingrad. Za Volgoy dlya nas zemli net [Stalingrad. There Is No Land for Us Beyond Volga]. Moscow, Eksmo; Yauza Publ., 2008. 448 p.

12. Isaev A.V. Stalingrad. Trudnoe nachalo [Stalingrad. Hard Start]. Rodina [Homeland], 2013, no. 1 , pp. 5-10.

13. Kolesnik A.D. RSFSR v Velikoy Otechestvennoy voyne [The Russian Soviet Federative Socialist Republic in the Great Patriotic War]. Moscow, Nauka Publ., 1982. $328 \mathrm{p}$.

14. Krinko E.F. Boevye deystviya na yuge Rossii v 1941-1943 gg.: istoriograficheskiy opyt i perspektivy dalneyshikh issledovaniy [Fighting in the South of Russia in 1941-1943: Historiographic Experience and Prospects for Further Research]. Znachenie srazheniy 1941-1943 gg. na yuge Rossii v Pobede v Velikoy Otechestvennoy voyne: materialy Vseros. nauch. konf. (Rostov-na-Donu, 3-6 iyunya 2015 g.) [Value of Battles of 1941-1943 in the South of Russia in the Victory in the Great Patriotic War: Proceedings of the All-Russian Academic Conference (Rostov-on-Don, June 3-6, 2015)]. Rostov-on-Don, SSC RAS Publ., 2015, pp. 22-27.

15. Kropachev S.A., Krinko E.F. Poteri naseleniya SSSR v 1937-1945 gg.: masshtaby iformy. Otechestvennaya istoriografiya [Losses of the Population of the USSR in 1937-1945: Scales and Forms. Russian Historiography]. Moscow, ROSSPEN Publ., 2012.350 p.

16. Liddell-Gart B.G. Vtoraya mirovaya voyna [World War II]. Moscow, Voenizdat Publ., 1976. 580 p.

17. Luganshchina v gody Velikoy Otechestvennoy voyny: Sbornik materialov $i$ dokumentov [Luhanshchyna in the Days of the Great Patriotic War. Collection of Materials and Documents]. Donetsk, Donbass Publ., 1969. 736 p. 
18. Milich A. Khorvatskie dobrovoltsy v germanskom vermakhte vo Vtoroy mirovoy voyne [The Croatian Volunteers in the German Wehrmacht in World War II]. Krestovyy pokhod na Rossiyu: sb. st. [The Crusade to Russia: Collection of Articles]. Moscow, Yauza Publ., 2005, pp. 375-402.

19. Moshchanskiy I.B. Oborona Stalingrada, 17 iyulya - 18 noyabrya $1942 \mathrm{~g}$. [Defense of Stalingrad, July 17 - November 18, 1942]. Moscow, BTV-KNIGA Publ., 2001. 83 p. (Series: Military chronicle "Battles and Fights"; 2001, no. 1).

20. Myuller-Gillebrand B. Sukhoputnaya armiya Germanii 1933-1945 gg. [Overland Army of Germany of 1933-1945]. Moscow, Izografus Publ.; Eksmo Publ., 2002.800 p.

21. Naselenie Rossii v XX veke: Istoricheskie ocherki. V 3 t. T. 2. 1940-1959 gg. [The Population of Russia in the $20^{\text {th }}$ Century. Historical Sketches. In 3 vols. Vol. 2. 1940-1959]. Moscow, ROSSPEN Publ., 2001. $416 \mathrm{p}$.

22. Pavlova T.A. Grazhdanskoe naselenie Stalingradskoy oblasti $v$ usloviyakh germanskoy okkupatsii: iyul 1942 g. -fevral 1943 g.. dis. ... kand. ist. nauk [The Civilian Population of the Stalingrad Region in the Conditions of the German Occupation: July 1942 - February 1943. Cand. hist. sci. diss.]. Saint Petersburg, 2007. 245 p.

23. Pavlova T.A. Zasekrechennaya tragediya: grazhdanskoe naselenie $v$ Stalingradskoy bitve [The Secret Tragedy: the Civilian Population in the Battle of Stalingrad]. Volgograd, Peremena Publ., 2005. 593 p.

24. Panin A., Pereslegin S. Stalingrad. Tsena pobedy [Stalingrad. Price of Victory]. Moscow; Saint Petersburg, AST Publ.; Terra Fantastica Publ., 2005. 331 p.

25. Postanovlenie Rostovskoy oblastnoy komissii po uchetu zverstv i ushcherba prichinennogo nemetsko-fashistskimi okkupantami grazhdanam, kolkhozam, gosudarstvennym predpriyatiyam, uchrezhdeniyam i organizatsiyam [The Resolution of the Rostov Regional Commission on Accounting of Atrocities and the Damage Caused by Fascist Invaders to Citizens, Collective Farms, the State Enterprises, Institutions and the Organizations]. Tsentr dokumentatsii noveyshey istorii Rostovskoy oblasti [The Center of Documentation of the Contemporary History of the Rostov Region], F. 1886, Op. 1, D. 22.

26. Matishov G.G., Krinko E.F., Afanasenko V.I., Medvedev M.V. Razgrom «natsistskogo internatsionala» na Donu (1942-1943) [Defeat of "Nazi International" on the Don (1942-1943)]. Vestnik Yuzhnogo nauchnogo tsentra RAN, 2015, vol. 11, no. 2, pp. 87-96.

27. Redkina O.Yu. Izuchenie istorii Stalingradskoy bitvy i vosstanovleniya Stalingrada v Volgogradskom gosudarstvennom universitete [Studying the History of the Battle of Stalingrad and Restoration of Stalingrad at the Volgograd State University]. Vestnik
Volgogradskogo gosudarstvennogo universiteta. Seriya 4, Istoriya. Regionovedenie. Mezhdunarodnye otnosheniya [Science Journal of Volgograd State University. History. Area Studies. International Relations], 2013, no. 1 (23), pp. 143-148. DOI: https:// doi.org/10.15688/jvolsu4.2013.1.23.

28. Roberts Dzh. Pobeda pod Stalingradom. Bitva, kotoraya izmenila istoriyu [Victory near Stalingrad. Fight Which Has Changed the History]. Moscow, URSS Publ., 2003. 175 p.

29. Samsonov A.M. Stalingradskaya bitva [The Battle of Stalingrad]. Moscow, Nauka Publ., 1989. 629 p.

30. Sovetskaya voennaya entsiklopediya. T. 7. [Soviet Military Encyclopedia. Vol. 7]. Moscow, Voenizdat Publ., 1980. 629 p.

31. Sokolov B.V. Tsena pobedy: Velikaya Otechestvennaya: neizvestnoe ob izvestnom [Victory Price: Great Patriotic War. The Unknown about the Known]. Moscow, Moskovskiy rabochiy Publ., 1991. $191 \mathrm{p}$.

32. Soobshcheniya Sovetskogo informbyuro. T. 4. Yanvar - iyun $1943 \mathrm{~g}$. [Messages of the Soviet Information Bureau. Vol. 4. January - June, 1943]. Moscow, Sovinformbyuro Publ., 1944. 400 p.

33. Spravka ob ustanovlennykh zlodeyaniyakh, sovershennykh nemetsko-fashistskimi zakhvatchikami i ikh soobshchnikami po rayonam Stalingradskoy oblasti (bez voennoplennykh) [The Reference on the Established Crimes Committed by Fascist Aggressors and Their Accomplices in the Districts of the Stalingrad Region (Without Prisoners of War)]. Tsentr dokumentatsii noveishei istorii Volgogradskoi oblasti [The Center of Documentation of the Contemporary History of the Rostov Region], F. 113, Op. 14, D. 13.

34. Stalin I.V. O Velikoy Otechestvennoy voyne Sovetskogo Soyuza [About the Great Patriotic War of the Soviet Union]. Moscow, Gospolitizdat Publ., 1952. $186 \mathrm{p}$.

35. Stalingrad. Sobytie. Vozdeystvie. Simvol [Stalingrad. Event. Influence. Symbol]. Moscow, Progress-Akademiya Publ., 1995. 528 p.

36. Zagorulko M.M., ed. Stalingradskaya bitva. Iyul 1942 - fevral 1943: entsiklopediya [Battle of Stalingrad. July 1942 - February 1943. The Encyclopedia]. Volgograd, Izdatel Publ., 2012. 800 p.

37. Stalingradskaya bitva: khronika, fakty, lyudi. Kn. vtoraya [Battle of Stalingrad: Chronicle, Facts, People. Book 2]. Moscow, Olma-Press, 2002. 573 p.

38. Stalingradskaya epopeya: Materialy NKVD SSSR $i$ voennoy tsenzury iz Tsentralnogo arkhiva FSB $R F$ [Stalingrad Epic. Proceedings of People's Commissariat for Internal Affairs of the USSR and Military Censorship from the Central Archive of the Federal Security Service of the Russian Federation]. Moscow, Zvonnitsa-MG Publ., 2000. 496 p. 


\section{ВОССТАНОВЛЕНИЕ СТРАЛИНГРАДА И ОБЛАСТИ}

39. Krinko E.F. The Nazi occupation and collaboration in the Stalingrad region (1942-1943). Journal of
International Network Center for Fundamental and Applied Research, 2016, no. 4,pp. 170-178.

\section{Information about the Authors}

Evgeniy F. Krinko, Doctor of Sciences (History), Chief Researcher, Southern Scientific Center of RAS, Director of Institute of Socio-Economic Research and Humanities, Southern Scientific Center of RAS, Prosp. Chekhova, 41, 344006 Rostov-on-Don, Russian Federation, krinko@ssc-ras.ru, https:// orcid.org/0000-0003-3008-5626

Maksim V. Medvedev, Junior Researcher of Southern Scientific Center of RAS, Junior Researcher of Institute of Socio-Economic Research and Humanities, Southern Scientific Center of RAS, Prosp. Chekhova, 41, 344006 Rostov-on-Don, Russian Federation; Postgraduate Student, Southern Federal University, Bolshaya Sadovaya St., 33, 344082 Rostov-on-Don, Russian Federation, m1max@mail.ru, https://orcid.org/0000-0002-8699-6405

\section{Информация об авторах}

Кринко Евгений Федорович, доктор исторических наук, главный научный сотрудник Южного научного центра РАН, директор Института социально-экономических и гуманитарных исследований Южного научного центра РАН, просп. Чехова, 41, 344006 г. Ростов-на-Дону, Российская Федерация, krinko@ssc-ras.ru, https:// orcid.org/0000-0003-3008-5626

Максим Валерьевич Медведев, младший научный сотрудник Южного научного центра РАН; младший научный сотрудник Института социально-экономических и гуманитарных исследований Южного научного центра РАН, просп. Чехова, 41, 344006 г. Ростов-на-Дону, Российская Федерация; аспирант, Южный федеральный университет, ул. Большая Садовая, 33, 344082 г. Ростов-на-Дону, Российская Федерация, m1max@mail.ru, https://orcid.org/0000-0002-8699-6405 